\title{
Remarks about biology of Canthon rutilans Laporte, 1840 (Coleoptera: Scarabaeidae) with the first report of perching in a Brazilian Tropical Dry Forest
}

\author{
Medina, AM. ${ }^{a *}$ and Campos, EM. ${ }^{b}$ \\ aPrograma de Pós-graduação em Zoologia, Departamento de Ciências Biológicas, Universidade Estadual de Feira de \\ Santana - UEFS, Av. Transnordestina, s/n, CEP 44036-900, Feira de Santana, BA, Brazil \\ 'Programa de Pós-graduação em Modelagem em Ciências da Terra e do Ambiente, Departamento de Ciências Exatas, \\ Universidade Estadual de Feira de Santana- UEFS, Av. Transnordestina, s/n, CEP 44036-900, Feira de Santana, BA, Brazil \\ *e-mail: bojaum@hotmail.com \\ Received February 14, 2012 - Accepted July 11, 2012 - Distributed May 31, 2013
}

Dung beetles are detritivorous organisms that can sometimes be found in leaves resting, stretching the antennae and moving their bodies (Young, 1984) and many explanations have been proposed for this intriguing behaviour (Louzada, 1998). There are 618 species registered for Brazil but little is known about their biology and ecology (Vazde-Mello, 2000). The aim of this paper is to contribute to the knowledge of dung beetles by registering biology and distribution records of Canthon rutilans, Laporte 1840.

Two areas of Caatinga, a Brazilian Tropical Dry Forest, were sampled. One Arboreal Caatinga in Milagres, BA $\left(12^{\circ} 54.53^{\prime} \mathrm{S}\right.$ and $\left.39^{\circ} 51.27^{\prime} \mathrm{W}\right)$ was sampled with baited pitfalls (rotten banana, cow dung, human faeces and bovine spleen) being emptied at 6 am and 6 pm for diet activity classification, during 12.vii.2010, 20.x.2010, 7.i.2011 and 15.iv.2011. The other area was in Senhor do Bonfim, BA $\left(10^{\circ} 22.19^{\prime} \mathrm{S}\right.$ and $\left.40^{\circ} 10.85^{\prime} \mathrm{W}\right)$ sampled during 07.vii.2005 and 22.i.2006 with baited pitfalls (human faeces and bovine spleen), this data was available at the Museu de Zoologia da Universidade Estadual de Feira de Santana (MZFS). All specimens were deposited in the MZFS.

One specimen of $C$. rutilans was registered in Milagres during perching activity on a leaf around $0.6 \mathrm{~m}$ high in the morning (9:00 AM), this behaviour was registered in Tropical Rain Forests, Subtropical and Temperate Forests and in Scarp Forest (Ballerio, 2008), however until now no report of dung beetle perching in a Tropical Dry Forest was made. Also 246 individuals were caught in pitfalls baited with bovine spleen (19.51\%) and human feces (80.49\%) for Milagres and 250 individuals (74\% in human feces) for Senhor do Bomfim. Thus revealing a coprophagous preference also registered in other studies (Audino et al., 2011), but which disagrees with other results that pointed out a necrophagous preference (Silva et al., 2008); however the latter used cow dung as bait which can be avoided in favour of human faeces or carrion since no beetle used cow dung in Milagres. Species had diurnal activity as $97.56 \%$ of individuals (Milagres data) were collected during the day and other studies had also shown this pattern (Hernández et al., 2011). Specimens of Milagres were metallic green and could be $C$. rutilans cyanescens Harold, 1868 albeit those from Senhor do Bomfim were metallic brown and could be C. rutilans rutilans Laporte, 1840.
Dung beetles had mean body length of $9.04 \pm 0.51 \mathrm{~mm}$ $(n=20)$ in Milagres and $9.63 \pm 0.93 \mathrm{~mm}(\mathrm{n}=20)$ in Senhor do Bonfim, and were smaller than those found in the Atlantic Forest $11.68 \pm 0.07 \mathrm{~mm}$ (Hernández et al., 2011). Mean body weights were $47 \pm 13 \mathrm{mg}$ in Milagres and $36 \pm 14 \mathrm{mg}$ in Senhor do Bomfim less than $59 \mathrm{mg}$ found in the Atlantic Forest (Condé, 2008). Possible differences between Atlantic Forest and Caatinga specimens could be either geographical differences as Canthon species has morphological variations (Medina et al., 2003) or a consequence of less mammal faeces available (Hernández, 2007) that could limit development in the larval stages.

Canthon rutilans was registered in the Atlantic Forest (Condé, 2008; Hernández and Vaz-de-Mello, 2009; Hernández et al., 2011; Korasaki et al., 2012), Pampas (Silva et al. 2008, 2009) and Eucalyptus plantations although showing preference for forest formations (Audino et al., 2011; Silva, 2011) and in the following Brazilian States: Paraná, Santa Catarina, São Paulo and Rio Grande do Sul. Hence this species is first registered in the Caatinga Biome and also through perching in a Tropical Dry Forest.

Acknowledgements - We thank CAPES for Medina, A.M. grant and FAPESB for Campos, E.M. grant. We are also grateful to M. A. Ulysséa, F. Camurugi and Ivan for field assistance.

\section{References}

AUDINO, LD., SILVA, PG., NOGUEIRA, JM., MORAES, LP. and VAZ-DE-MELLO, FZ., 2011. Scarabaeinae (Coleoptera, Scarabaeidae) de um bosque de eucalipto introduzido em uma região originalmente campestre. Iheringia, Série Zoologia, vol. 101, no. 1-2, p. 121-126. http://dx.doi.org/10.1590/S007347212011000100017

BALLERIO, A., 2008. First report of perching behaviour by dung beetles (Coleoptera: Scarabaeidae: Scarabaeinae) in scarp forests of KwaZulu-Natal, South Africa. African Entomology, vol. 16, no. 1, p. 132-133. http://dx.doi.org/10.4001/1021-3589-16.1.132

CONDÉ, PA., 2008. Comunidade de Besouros Scarabaeinae (Coleoptera: Scarabaeidae) em duas áreas de Mata Atlântica do Parque Municipal da Lagoa do Peri, Florianópolis-SC: Subsídios para o Biomonitoramento Ambiental. Available in http://www. ccb.ufsc.br/biologia/TCCsemestresanteriores.htm

HERNÁNDEZ, MIM., 2007. Besouros Escarabeíneos (Coleoptera: Scarabaeidae) da Caatinga Paraibana, Brasil. Oecologia 
Brasiliensis, vol. 11, no. 3, p. 356-364. http://dx.doi.org/10.4257/ oeco.2007.1103.06

HERNÁNDEZ, MIM. and VAZ-DE-MELLO, FZ., 2009. Seasonal and spatial species richness variation of dung beetle (Coleoptera, Scarabaeidae s. str.) in the Atlantic Forest of southeastern Brazil. Revista Brasileira de Entomologia, vol. 53, no. 4, p. 607-613. http://dx.doi.org/10.1590/S0085-56262009000400010

HERNÁNDEZ, MIM., MONTEIRO, LR. and FAVILA, ME., 2011. The Role of Body Size and Shape in Understanding Competitive Interactions within a Community of Neotropical Dung Beetles. Journal of Insect Science, vol. 11 no. 13, p. 1-14. http://dx.doi. org/10.1673/031.011.0113

KORASAKI, V., LOPES, J., BROWN, GG. and LOUZADA, J., 2012. Using dung beetles to evaluate the effects of urbanization on Atlantic Forest biodiversity. Insect Science, vol. 20, no. 3, p. 393-406. http://dx.doi.org/10.1111/j.1744-7917.2012.01509.x

LOPES, J., KORASAKI, V., CATELLI, LL., MARÇAL, VVM. and NUNES, MPBP., 2011. A comparison of dung beetle assemblage structure (Coleoptera: Scarabaeidae: Scarabaeinae) between an Atlantic Forest fragment and adjacent abandoned pasture in Paraná, Brazil. Zoologia, vol. 28, no. 1, p. 72-79. http://dx.doi. org/10.1590/S1984-46702011000100011

LOUZADA, JNC., 1998. Consideration on the Perching Behaviour of Tropical Dung Beetles (Coleoptera, Scarabaeidae). Revista Brasileira de Entomologia, vol. 41, no. 2, p. 125-128.
MEDINA, CA., SCHOLTZ, CH. and GILL, BD., 2003. Morphological variation and systematics of Canthon Hoffmansegg 1817, and related genera of new world Canthonini dung beetles (Coleoptera, Scarabaeinae). Deutsche Entomologische Zeitschrift, vol. 50, no. 1, p. 23-68.

SILVA, PG., 2011. Dung Beetles (Coleoptera: Scarabaeidae: Scarabaeinae) of Two Non-Native Habitats in Bagé, Rio Grande do Sul, Brazil. Zoological Studies, vol. 50, no. 5, p. 546-559.

SILVA, PG., GARCIA, MAR. and VIDAL, MB., 2008. Besouros copro-necrófagos (Coleoptera: Scarabaeidae stricto sensu) coletados em ecótono natural de campo e mata em Bagé, RS. Ciência e Natura, vol. 30, no. 2, p. 71-91.

-, 2009. Adultos de Scarabaeidae sensu stricto (Coleoptera) coletados em áreas naturais de campo e de floresta, em Bagé, RS. Revista de Ciências Agroveterinárias, vol. 8, no. 1, p. 62-65.

VAZ-DE-MELLO, FZ., 2000. Estado atual de conhecimento dos Scarabaeidae S. Str. (Coleoptera: Scarabaeoidea) do Brasil. In MARTÍN-PIERA, F., MORRONE, JJ. and MELIC, A. (Eds.). Hacia un proyecto CYTED para el inventario y estimación de la diversidad entomológica en Iberoamérica: PrIBES-2000. Zaragoza: m3m: Monografías Tercer Milenio. p. 183-195.

YOUNG, OP., 1984. Perching of Neotropical Dung Beetles on Leaf Surfaces: An Example of Behavioural Thermoregulation? Biotropica, vol. 16, no. 4, p. 324-327. 